\title{
Genetics of Shoot Fly Resistance in a Recombinant Inbreed Lines Population of Sorghum [Sorghum bicolor (L.) Moench]
}

\author{
S.P. Mehtre ${ }^{1}$, C.T. Hash ${ }^{2}$, H.C. Sharma ${ }^{2}$, S.P. Deshpande ${ }^{2}$ and G.W. Narkhede ${ }^{1 *}$ \\ ${ }^{1}$ Vasantrao Naik Marathwada Krishi Vidyapeeth, Parbhani 431402 (MS) India \\ ${ }^{2}$ International Crops Research Institute for the Semi-Arid Tropics (ICRISAT), \\ Patancheru, 502324, Telangana India
}

\begin{abstract}
A B S T R A C T
Sorghum shoot fly [Atherigona soccata (Rondani)] is one of the most important pests of grain sorghum. It is important to understand the nature of gene action to breed for resistance to the target insect pest. In the present study, a population of 259 sorghum recombinant inbred lines (RILs) derived from cross 296B (shoot fly susceptible) x IS 18551 (shoot fly resistant) were evaluated in shoot fly screening nursery to study the inheritance of shoot fly resistance. Variances due to RIL genotypes (G), screening environment $(\mathrm{E})$ and $\mathrm{G} \times \mathrm{E}$ interactions were significant for the traits studied. Normal distribution of RIL means suggested quantitative inheritance of trait studied. Heritability (broad sense) estimates for glossiness intensity, oviposition incidence (\%) and dead hearts incidence (\%) were consistent in individual and low across environment analyses indicating that, these traits can be used as reliable parameters to select a plant with resistance to shoot fly. High broad sense heritability estimates were recorded for trichome densities (on both upper and lower leaf blades), but exhibited significant $G \times \mathrm{E}$ interactions. Transgressive sergeants with phenotypic values outside the parental limits were observed for oviposition (\%), dead heart (\%) and trichome density. Utilization of RILs 46, 208, 222 and 223 (kharif season adaptation) and RILs 47, 51, 82, 97, 130 and 174 (rabi season adaptation) which exhibited shoot fly resistance combined with better agronomic feature will be useful in sorghum shoot fly resistance breeding.
\end{abstract}

\section{Keywords}

Shoot fly,

Atherigona soccata, Recombinant inbred lines (RILs),

Glossiness,

Trichome density, Genetics

Article Info

Accepted:

26 February 2019

Available Online:

10 March 2019

\section{Introduction}

Sorghum [Sorghum bicolor (L.) Moench] is the fifth most important cereal crop worldwide (FAO STAT 2004) and an important rainfed cereal crop in the semi-arid tropics (SAT). India is the major producer of sorghum with the crop occupying 9.9 million hectares with an annual production of 8.0 million metric tones during 2003-2004 (FAS 2005). Genetic manipulation of sorghum in India since the 1960s has led to the development of several high yielding varieties and hybrids. However, many of these were highly susceptible to shoot fly [Antherigona soccata (Rondani)] which often resulted in severe damage to the crop (Rao and Rao, 1956; Jotwani and Srivastava, 1970). Adoption of chemical control is not 
economically feasible for resource-poor farmers of the semi-arid tropics (SAT), as the low crop value per acre precludes the use of insecticides for control of shoot fly (Dhamas, 1943). Therefore host plant resistance combined with non-monitory input like timely sowing is the most realistic approach to minimize grain and stover yield losses.

Blum (1967) observed that resistance to shoot fly in sorghum is due to ovipositional nonreference, which becomes ineffective when shoot fly populations are high (Jotwani and Srivastava, 1970). Glossy leaves (Agrawal and House, 1982), seedling vigor (Jadhav et al., 1986) and trichomes on the abaxial leaf blade (Mati and Bidiger, 1979) are reported to be the main factors responsible to shoot fly resistance.

The selection of shoot fly resistant sorghum genotypes by utilizing any one of the above resistance factors is inefficient due to several components involved in imparting resistance. Moreover each of these factors are governed by one or more genes and exhibit considerable genotype $(\mathrm{G}) \mathrm{x}$ environment $(\mathrm{E})$ interaction.

Genetic analysis of quantitative traits requires replicated multi-environment testing because of the un-replicability of field screening environments and possible $G \times x$ interactions. This can be accomplished by using a population of recombinant inbred lines (RILs), as it constitutes a permanent seed source of multiple field screenings (Burr et al., 1988) and as each genotype in the RIL population is represented by a progeny, rather than by an individual a more accurate assessment of the genetic component of variance can be made in studying the quantitative traits. Hence, the present study was undertaken to study the genetic architecture of shoot fly resistance under varying levels of shoot fly infestation by using a sorghum RIL populations.

\section{Materials and Methods}

Studies on the genetics of shoot fly resistance in a sorghum RIL population were conducted in two screening environments at International Crops Research Institute for the Semi-Arid Tropics (ICRISAT), Patancheru, India during late kharif (sown on $16^{\text {th }}$ August 2002) and early rabi (sown on $16^{\text {th }}$ October 2004) season. The experimental material consisted of a set of $259 \mathrm{~F}_{7}$ RILS derived from a cross between two sorghum inbred lines viz. 296B (derived from Aispuri and susceptible to shoot fly) and IS 18551 (originating from Ethiopia and resistant to shoot fly). After the initial cross between $296 \mathrm{~B}$ and IS 18551, a single $\mathrm{F}_{1}$ plant was selfed and the resulting $\mathrm{F}_{2}$ seeds were sown to produce $F_{2}$ plants. Selfing of $F_{2}$ plants produced $\mathrm{F}_{3}$ seeds, which were sown head to row. Each $F_{3}$ plant was selfed and from each head-to-row plot, a single plant randomly chosen to provide seeds for the next generation. This modified single seed descent method, where each line was advanced using a single randomly selected plant, was repeated for 3 to 4 generations. Recommended protections measures were taken during RIL population development at ICRISAT to minimize selection for shoot fly resistance. Each of the resulting $259 \mathrm{~F}_{7}$ lines represented the single $F_{2}$ plant from which it is derived. Screening of the RIL for shoot fly resistance was carried out at the ICRISAT, Patancheru, Andhra Pradesh, India. A total of 300 lines (259 RILs +14 times repeated checks of each of 296B and IS18551) and a standard check, CSH-9, repeated 13 times) were sown on $16^{\text {th }}$ August during 2002 kharif season (E1), for early rabi season (E2), a total of 270 entries (259 RILs + 4 times repeated checks of each of 296B and IS18551 + standard check CSH 9 repeated 3 times), were sown on $16^{\text {th }}$ October 2004. The test material was planted in balanced design, with $75 \mathrm{~cm}$ and $15 \mathrm{~cm}$ inter and intra-row spacing respectively. In the late kharif and rabi seasons, each entry was grown in two-row plot of $2 \mathrm{~m}$ length in four and three 
replications respectively. Shoot fly infestation was quite high during the kharif season. During the rabi season, the shoot fly infestation was relatively low to ensure uniform and optimum shoot fly infestation under field condition. The interlard fish meal technique (Sharma et al., 1992) was followed to screen for resistance to shoot fly. Observations on glossiness were recorded at 7 days after emergence (DAE) scored visually 1 to 5 scale $(1=$ highly glossy and $5=$ uniformly non-glossy). The leaf glossiness score was recorded before thinning at $7 \mathrm{DAE}$, and plant counts per plot were taken the next day. Oviposition counts were taken at $14 \mathrm{DAE}$ (I) and 21 DAE (II) and oviposition incidence was recorded as the percentage of plants with eggs. While dead hearts counts were taken at 21 DAE (I) and 28 DAE (II) and dead heart incidence was recorded as a percentage of plants with dead hearts. Trichome density on the central portion of the fifth leaf from the base was recorded (no. of trichome per microscopic field on upper and lower leaf blades) at 17 DAE in both screening environments. Agronomic traits such as time to $50 \%$ flowering (days), plant height $(\mathrm{cm})$ and grain yield $\left(\mathrm{gm}^{2}\right)$ were also recorded.

The analysis of variance for phenotypic data sets were performed using the residual maximum likelihood algorithm (REML), which estimates the components of variance by maximizing the likelihood of all contrasts with zero expectation (Paterson and Thompson 1971) and provides best linear unbiased predictions (BLUPs) of the performance of the genotypes. For each trait and for each entry, the predicted means were calculated with replications as fixed effects and entries with replication $\mathrm{x}$ block as a random effect for both individual environments (seasons). For across screening environment (seasons) analyses, environment and replications were treated as fixed effect and entries, environment $\mathrm{x}$ entries, and environment $\mathrm{x}$ replication interactions as random effects. The data was analyzed using the Genestat $\left(6^{\text {th }}\right.$ edition) software package (Payne 2002).

\section{Results and Discussion}

The mean performance of the two parents (296B and IS18551) revealed significant phenotypic differences (Table 1) for shoot fly resistance and other agronomic traits except for time to $50 \%$ flowering (days) in kharif and grain yield in rabi. Parental performance under different environments varied for all the traits except for glossiness. For glossiness intensity, the parental and RIL mean performances were consistent across the two seasons. Similar observations have been reported by Jayanthi et al., (1999). Parental mean values and RIL ranges for oviposition I, II and dead hearts I, II indicated greater shoot fly pressure in kharif than in the rabi screening environment. The range of the RIL mean values for oviposition and dead hearts incidence clearly indicated that shoot fly population pressure in both screening environment was high to optimal as it allowed expression of a wide range of phenotypic values. Borikar et al., (1982) observed higher variability when the material was tested under optimum shoot fly population levels. While Rana et al., (1975) reported that selection for shoot fly resistance was effective under conditions when morality ranged from 7 to $67 \%$.

Trichome density was quite consistent across seasons but was greater in rabi season than to kharif season and greater on upper leaf blade than on lower leaf blade. Similar observations were revealed by Mati and Gibson (1983), Borikar and Chundurwar (1989) and Sajjanar (2002). Elite shoot fly susceptible parent 296B was late in flowering, shorter in height and lower yielding than IS18551 in both the screening environments, although some of the differences observed may have been due to the confounding influence of differential 
susceptibility to shoot fly. The wide variation observed in the RIL population for glossiness intensity, oviposition, dead heart incidence, and trichome density indicated that the population can be used to map quantitative trait loci (QTLs) governing these traits, provided that sufficient marker polymorphism can be detected between the parents to track, genome-wide segregation patterns.

The genotypic variances for glossiness, oviposition I, II, dead heart I, II, trichome density (upper and lower leaf blades), time to $50 \%$ flowering, plant height and grain yield were greater than the corresponding variances for $\mathrm{G} \times \mathrm{E}$ interaction (Table 2) indicating that these traits are under genetic control although $\mathrm{G} \times \mathrm{E}$ interactions had significant influence on in their expression. Similar results have been reported by Jayanthi et al., (1999), and the differential response of sorghum genotypes to variation in photoperiod, measured in terms of flowering time and plant height is well known.

Components traits associated with shoot fly resistance showed low to moderate broad sense heritability estimates (Table 3). Consistently high heritability estimates were observed for glossiness in two individual screening environments and moderate estimates across these two test environment indicated that contributions to phenotypic variance due to environmental factors and $\mathrm{G} x$ $E$ interaction are less than, genotype factors as evident from values of genotype and $G \times E$ variances. The $G \times E$ variance component is, however significant indicating the complex nature of glossiness. Agrawal and Abranam (1985) indicated that the seedling glossiness intensity is quantitative in nature and controlled by both additive and non-additive genes. Oviposition and dead heart incidence recorded, low to moderate but consistent operational heritability estimates in the two individual screening environments and also at different stages of observation. However, operational heritability estimates for these traits across seasons for both observation stages were low indicating a prominent role of screening environment and/or genotype $\mathrm{x}$ environment interaction in the expression of the trait. This observation corroborates by Halalli et al., (1983), Borikar and Chopde (1982) and Borikar et al., (1982).

Consistently high heritability estimates were recorded in both screening environments for trichome density on upper and lower leaf blades, while across season analyses revealed lower heritability estimates for trichome densities of both leaf blades ( $\mathrm{h} 2=0.51$ for upper and $\mathrm{h} 2=0.49$ for lower leaf blade). This indicates the role of environmental factors and $\mathrm{G} \times \mathrm{E}$ factor in the expression of this trait. The result obtained in this study reveals that there are strong seasonal effects on the expression of trichome density. These results are in agreement with those of Jayanthi et al., (1999) and Sajjanar (2002).

The analysis revealed that RIL means differed significantly from both the parents to shoot fly resistance traits (Table 4). Transgressive sergeants with phenotypic values outside the parental limits were observed for most of the shoot fly resistant traits except for leaf glossiness. For oviposition, I, II, dead heart I, II and grain yield, the RIL population mean was less than the mid-parental value. In contrast to glossiness, the trichome density (both on upper and lower leaf blades) and plant height, RIL population mean values were greater than the mid-parental value. In general, the proportion of RIL outside the parental limits was greater for those outside the low-scoring parents and lower for outside high scoring parents. The expectation of equal frequencies of inbreeds lying outside the limits of either parent was not observed in any case. This shows that, for shoot fly resistance and its component traits, there were epistatic interactions (predominance of additive $\mathrm{x}$ additive gene action) influencing trait expression in this RIL population. 
Table.1 Mean, the standard error for two parents and mean, the range of RILs derived from $296 \mathrm{~B} \times$ IS 18551 mapping population for different components of resistance to shoot fly and agronomic traits in two screening environments at ICRISAT,

Patancheru during $2002-04$

\begin{tabular}{|c|c|c|c|c|c|c|c|c|c|c|}
\hline \multirow[t]{2}{*}{ Character } & \multicolumn{5}{|c|}{ E1 (kharif) Patancheru } & \multicolumn{5}{|c|}{ E2 (rabi) Patancheru } \\
\hline & $\underset{(296 B)}{\text { P1 }}$ & $\begin{array}{c}\text { P2 } \\
\text { (IS 18551) }\end{array}$ & $\mathbf{S E} \pm$ & $\begin{array}{l}\text { RIL } \\
\text { mean }\end{array}$ & Range & $\begin{array}{c}\text { P1 } \\
(296 B)\end{array}$ & $\begin{array}{c}\text { P2 } \\
\text { (IS 18551) }\end{array}$ & $\mathbf{S E} \pm$ & $\begin{array}{l}\text { RIL } \\
\text { mean }\end{array}$ & Range \\
\hline Glossiness Intensity (scale) & $5.0 * *$ & $1.0 * *$ & 0.26 & 3.6 & $1.0-5.0$ & $5.0 * *$ & $1.1 * *$ & 0.35 & 3.5 & $1.3-5.0$ \\
\hline Oviposition I (\%) & $68.7 * *$ & $45.0 * *$ & 5.71 & 61.2 & $41.0-81.0$ & $55.2 * *$ & $15.5^{* *}$ & 7.4 & 35.0 & $0.0-72.6$ \\
\hline Oviposition II (\%) & $95.5^{* *}$ & $79.0 * *$ & 3.42 & 89.7 & $75.1-99.2$ & $81.2 * *$ & $33.1 * *$ & 6.6 & 57.8 & $16.7-90.7$ \\
\hline Deadhearts I (\%) & $75.7 * *$ & $51.5^{* *}$ & 3.73 & 73.3 & $53.0-85.0$ & $60.0 * *$ & $17.0 * *$ & 7.6 & 35.1 & $5.6-76.0$ \\
\hline Deadhearts II (\%) & $96.0 * *$ & $68.5^{* *}$ & 2.45 & 87.7 & $69.0-97.0$ & $77.4 * *$ & $25.8 * *$ & 6.6 & 50.6 & $25.9-83.6$ \\
\hline $\begin{array}{l}\text { Trichome density upper leaf } \\
\text { blade (no./microscopic field) }\end{array}$ & $0.0 * *$ & $152.2 * *$ & 6.70 & 80.6 & $0.0-213.0$ & $0.0 * *$ & $189.7 * *$ & 7.9 & 87.3 & $0.0-240.0$ \\
\hline $\begin{array}{l}\text { Trichome density lower leaf } \\
\text { blade (no./microscopic field) }\end{array}$ & $0.0 * *$ & $73.0 * *$ & 3.86 & 32.0 & $0.0-92.7$ & $0.0 * *$ & $83.1 * *$ & 4.9 & 43.7 & $0.0-137.7$ \\
\hline Time to $50 \%$ flowering (days) & 89.4 & 87.8 & 2.00 & 83.4 & $67.0-97.0$ & $82.0 * *$ & $75.00 * *$ & 1.8 & 72.8 & $61.0-84.0$ \\
\hline Plant height (cm) & $110.5 * *$ & $244.0 * *$ & 8.94 & 194.6 & $118-284$ & $105.0 * *$ & $161.5^{* *}$ & 7.7 & 165.9 & $100-218$ \\
\hline Grain yield (gm/plot) & $194.0 * *$ & $1074.0 * *$ & 100.0 & 519.1 & $87-1120$ & 393.0 & 539.00 & 110 & 479.0 & $56-1018$ \\
\hline
\end{tabular}


Table.2 Genotype variances, GXE interaction and respective standard errors for components of resistance to shoot fly and other traits in sorghum RIL mapping population derived from cross 296B $\times$ IS 18551 under individual and across season screening environment

\begin{tabular}{|c|c|c|c|c|c|c|c|c|c|}
\hline \multirow{2}{*}{$\begin{array}{l}\text { Sr. } \\
\text { No. }\end{array}$} & \multirow[t]{2}{*}{ Character } & \multicolumn{2}{|c|}{ E 1 (late kharif) } & \multicolumn{2}{|c|}{ E 2 (rabi) } & \multicolumn{4}{|c|}{ E1-E2 (across season) } \\
\hline & & $6^{2} g$ & $\mathrm{SE}_{ \pm}$ & $6^{2} g$ & $\mathbf{S E}_{ \pm}$ & $6^{2} g$ & $\mathrm{SE}_{ \pm}$ & $6^{2} \mathrm{gxe}$ & $\mathrm{SE}_{ \pm}$ \\
\hline 1. & Glossiness intensity & $3.08 * *$ & 0.27 & $3.21 * *$ & 0.35 & $4.6^{* *}$ & 0.21 & $1.7 * *$ & 0.34 \\
\hline 2. & Oviposition I (\%) & $166.2 * *$ & 5.7 & $493.5^{* *}$ & 7.4 & $363.2 * *$ & 4.5 & $299.8^{* *}$ & 7.2 \\
\hline 3. & Oviposition II (\%) & $75.1^{* *}$ & 3.4 & $432.3 * *$ & 6.6 & $255.8 * *$ & 3.4 & $250.7 * *$ & 5.2 \\
\hline 4. & Deadhearts I (\%) & $144.6^{* *}$ & 3.7 & $856.2 * *$ & 7.6 & $330.2 * *$ & 3.8 & $274.1 * *$ & 5.9 \\
\hline 5. & Deadhearts II (\%) & $99.4 * *$ & 2.5 & $410.8 * *$ & 6.6 & $266.8 * *$ & 3.1 & $242.6^{* *}$ & 4.8 \\
\hline 6. & $\begin{array}{l}\text { Trichome density upper leaf blade } \\
\text { (no./microscopic field) }\end{array}$ & $11309.1 * *$ & 4.8 & $8685.9 * *$ & 8.10 & $13317.7 * *$ & 4.6 & $6571.2 * *$ & 7.10 \\
\hline 7. & $\begin{array}{l}\text { Trichome density lower leaf blade } \\
\text { (no./microscopic field) }\end{array}$ & $2064.5^{* *}$ & 2.9 & $2615.7 * *$ & 4.9 & $3092.1 * *$ & 2.7 & $1583.8 * *$ & 4.10 \\
\hline 8. & Time to $50 \%$ flowering (days) & $129.1 * *$ & 2.1 & $68.3 * *$ & 1.8 & $141.4 * *$ & 1.5 & $56.9 * *$ & 2.30 \\
\hline 9. & Plant height $(\mathrm{cm})$ & $4362.2 * *$ & 9.1 & $1263.4 * *$ & 6.9 & $4927.5^{* *}$ & 6.6 & $793.6^{* *}$ & 10.4 \\
\hline 10. & Grain yield (gm/plot) & $160726.0 * *$ & 99.0 & $7563.0 * *$ & 190.0 & $152599 * *$ & 73.7 & $83873 * *$ & 115.3 \\
\hline
\end{tabular}


Table.3 Operational heritability estimates (broad sense entry mean basis) for components of resistance to shoot fly and other traits in sorghum RIL population derived from cross 296B x IS18551 evaluated under two screening environments and across environments at Patancheru

\begin{tabular}{|c|c|c|c|}
\hline Character & $\begin{array}{c}\text { E1 } \\
\text { (kharif, Patancheru) }\end{array}$ & $\begin{array}{l}\text { E2 } \\
\text { (rabi, Patancheru) }\end{array}$ & $\begin{array}{l}\text { E1 E2 } \\
\text { (across seasons) }\end{array}$ \\
\hline Glossiness intensity (scale) & 0.90 & 0.88 & 0.64 \\
\hline Oviposition I (\%) & 0.20 & 0.67 & 0.17 \\
\hline Oviposition II (\%) & 0.38 & 0.70 & 0.02 \\
\hline Deadhearts I (\%) & 0.62 & 0.63 & 0.17 \\
\hline Deadhearts II (\%) & 0.74 & 0.68 & 0.09 \\
\hline $\begin{array}{l}\text { Trichome density upper leaf blade (no./microscopic } \\
\text { field) }\end{array}$ & 0.98 & 0.98 & 0.51 \\
\hline Trichome density lower leaf blade (no./microscopic field) & 0.97 & 0.97 & 0.49 \\
\hline Time to $50 \%$ flowering (days) & 0.87 & 0.85 & 0.60 \\
\hline Plant height (cm) & 0.91 & 0.86 & 0.84 \\
\hline Grain yield (gm/plot) & 0.75 & 0.53 & 0.45 \\
\hline
\end{tabular}


Table.4 Means of parents, the RIL population, their difference and proportion of RILs with values outside the parental limits based on pooled means over two screening environments

\begin{tabular}{|c|c|c|c|c|c|c|c|c|}
\hline \multirow[t]{2}{*}{ Character } & \multirow[t]{2}{*}{$\begin{array}{c}\text { P1 } \\
\text { 296B }\end{array}$} & \multirow[t]{2}{*}{$\begin{array}{c}\text { P2 } \\
\text { IS } \\
18551\end{array}$} & \multirow[t]{2}{*}{$\begin{array}{c}\text { Midparent } \\
\text { al } \\
\text { value }\end{array}$} & \multirow{2}{*}{$\begin{array}{l}\text { RIL } \\
\text { populatio } \\
\text { n mean }\end{array}$} & \multicolumn{2}{|c|}{$\begin{array}{c}\text { Test of } \\
\text { significance } \\
\text { of means }\end{array}$} & \multicolumn{2}{|c|}{$\begin{array}{c}\text { Proportions } \\
\text { outside the } \\
\text { parental limits }\end{array}$} \\
\hline & & & & & $\begin{array}{c}\text { P1/RI } \\
\text { L }\end{array}$ & P2/RIL & D1 & $\mathbf{P 2}$ \\
\hline Glossiness intensity (scale) & 5.0 & 1.1 & 3.0 & 3.6 & $* *$ & $* *$ & 0.000 & 0.000 \\
\hline Oviposition I (\%) & 66.3 & 40.9 & 53.6 & 49.9 & $* *$ & $* *$ & 0.015 & 0.092 \\
\hline Oviposition II (\%) & 93.0 & 72.6 & 82.8 & 76.1 & $* *$ & ns & 0.003 & 0.281 \\
\hline Deadhearts I $(\%)$ & 72.9 & 46.8 & 59.9 & 56.9 & $* *$ & $* *$ & 0.015 & 0.054 \\
\hline Deadhearts II (\%) & 92.6 & 62.6 & 77.6 & 71.8 & $* *$ & $* *$ & 0.000 & 0.057 \\
\hline $\begin{array}{l}\text { Trichome density upper leaf } \\
\text { blade (no./microscopic field) }\end{array}$ & 0.0 & 157.4 & 78.7 & 83.6 & $* *$ & $* *$ & 0.000 & 0.042 \\
\hline $\begin{array}{l}\text { Trichome density lower leaf } \\
\text { blade (no./microscopic field) }\end{array}$ & 0.0 & 74.4 & 37.2 & 37.7 & $* *$ & $* *$ & 0.000 & 0.039 \\
\hline Plant height (cm) & 109.5 & 232.3 & 170.9 & 182.3 & $* *$ & $* *$ & 0.000 & 0.015 \\
\hline Grain yield (g/plot) & 228.7 & 999.6 & 614.2 & 502.1 & $* *$ & $* *$ & 0.027 & 0.000 \\
\hline
\end{tabular}


The further occurrence of transgressive segregants indicates that both parental lines of the RIL population carried both desirable and undesirable alleles at various loci governing the traits. These results are in agreement with Borikar and Chopde (1981). Continuous distribution for shoot fly resistance traits revealed their quantitative inheritance. Considering the complex nature of shoot fly resistance revealed by the present study, direct transfer of shoot fly resistance from donor IS 18551 to an elite background such as 296B will probably require many cycles of crossing and selection. Therefore utilization of agronomically desirable RILS 46, 208, 222 and 223 (kharif season adoption) and RILS 47, 51, 82, 97, 130 and 174 (rabi season adoption) in shoot fly resistance breeding is likely to be more fruitful than direct use of an agronomically deficient source like IS18551.

\section{References}

Agrawal, B.L. and C.V. Abraham. 1985. Breeding sorghum for resistance to shoot fly [Atherigona soccata] and midge [Contarinia sorghicola]. Proceedings of the International Sorghum Entomology Workshop, 1521 July 1984, Texas A \& M University, College Station, TX, USA, pp. 371-383.

Agrawal, B.L. and L.R. House. 1982. Breeding for pest resistance in sorghum. In: Sorghum in the Eighties, Proceedings of the International Symposium on Sorghum, 2-7 November 1981, International Crops Research Institute for the Semi-Arid Tropics, Patancheru, AP, India, pp.435-446.

Blum, A. 1967. Varietal resistance of sorghum to the sorghum shoot fly [Atherigona varia soccata]. Crop Sci. 7: 461-462.

Borikar, S.T. and P.R. Chopde. 1981. Shoot fly resistance in sorghum. Indian J. Genet. 41: 191-199.

Borikar, S.T. and P.R. Chopde. 1982. Genetics of resistance to sorghum shoot fly. Z. Pflanzenzüchtg, 88: 220224.

Borikar, S.T. and R.D. Chundurwar. 1989. Genetic analysis for trichome density in Sorghum bicolor (L.) Moench. J. Maharashtra Agric. Univ. 14: 304305.

Borikar, S.T., R.D. Chundurwar and P.R. Chopde. 1982. Genetic variability for shoot fly resistance in sorghum. J. Maharashtra Agric. Univ. 7: 223-225.

Burr, B., F.A. Burr, K.H. Thomson, M.C. Albertson and C.W. Stubber. 1988. Gene mapping with recombinant inbreds in maize. Genetics, 118: 518526.

Dhams, R.G. 1943. Insect resistance in sorghum and cotton. Amer. Soc. Agron. J. 35: 704-715.

FAOSTAT. 2004. http://apps.fao.org/default. htm

FAS. 2005. http://fas.usda.gov/ FAS Online. United States Department of Agriculture, Foreign Agricultural Service.

Halalli, M.S., B.T.S. Gowda, K.A. Kulkarni and J.V. Goud. 1983. Evaluation of advanced generations progenies for resistance to shoot fly in sorghum. Indian J. Genet. 43: 291-293.

Jadhav, S.S., U.N. Mote and D.R. Bapat.1986. Biophysical plant characters contributing to shoot fly resistance. Sorghum Newslett. 29: 70.

Jayanthi, P.D.K., B.V.S. Reddy, T.B. Gour and D.D.R. Reddy. 1999. Genetics of glossy and trichome characters in sorghum hybrids of cytoplasmic male sterile lines. J. Maharashtra Agric. Univ. 24: 251-256.

Jotwani, M.G., K.K. Marwaha, K.M. Srivastava and W.R. Young. 1970. 
Seasonal incidence of shoot fly (Atherigona soccata Rond.) in jowar hybrids at Delhi. Indian J. Ent. 32: 715.

Maiti, R.K. and F.R. Bidinger. 1979. A simple approach to identification of shoot fly resistance in sorghum. Indian J. Pl. Protec. 7: 135-140.

Maiti, R.K. and P.T. Gibson. 1983. Trichomes in segregating generations of sorghum matings. II. Association with shoot fly resistance. Crop Sci. 23: 76-79.

Paterson, H.D. and R. Thompson.1971. Recovery of inter-block information when block sizes are unequal. Biometrika, 58: 545-554.

Payne, R.W. (Ed.) 2002. The Guide to
Genestat ${ }^{\circledR}$ Release 6.1. Part 2: Statistics. VSN International Ltd., Oxford, U.K.

Rana, B.S., D.P. Tripathi, K. Balakotaiah, R. Damodar and N.G.P. Rao. 1975. Genetic analysis of some exotic $\times$ Indian crosses in sorghum XI. Selection for shoot fly resistance. Indian J. Genet. 35: 350-354.

Sajjanar, G.M. 2002. Genetic analysis and molecular mapping of components of resistance to shoot fly (Atherigona soccata) in sorghum [Sorghum bicolor (L.) Moench.]. Ph.D. Thesis, University of Agricultural Sciences, Dharwad.

\section{How to cite this article:}

Mane, P.N., Manjusha S. Gaikwad, Prerna B. Chikte and Makarand P. Shinde. 2019. Integrated Management of Alternaria Leaf Blight and Necrosis of Sunflower. Int.J.Curr.Microbiol.App.Sci. 8(03): 2603-2612. doi: https://doi.org/10.20546/ijcmas.2019.803.308 